
no line or a single syllable of that Bill has erer been discussed either in the Council or in the meetings by the Fellows of the Society, and, further, the unseemliness of allowing the Legislature and community to be led to the belief that the Obstetrical Society was in its farour ; under these ciroumstances $I$ hare invited the Council to call a meeting of the Fellows in order that the Bill might be discussed, supporting this with a request signed by three Fellows of considerable standing in the society, one of them an ex.President, but this inritation was not accepted. have called attention to the conduct of business at the last annual meeting, and mored a resolution proposing the formation of a committee to revise the rules relating to the public business of the society. The resolution was lost. Since this was the last constitutional step I could take by war of protest. I feel that there is no longer any reason for me to remain in a position in which $I$ can be of no service to those who elected me and which is most distasteful to myself.

"The President of the Obstetrical Society of London."

LOYELL DRAge.

"Obstetrical Society of London, JuIy 22nd, 1896. "DAar SIR,-I beg to acknowledge the receipt of your letter resigning your seat on the Council of this society.

"Dr. Lovell Drage." "F. H, ChdMrexey.

\section{NURSING HOMES AND SECRET COMMISSIONS.}

To the Editors of THe LANCET.

SiRs,- The Lord Chief Justice recently said in reference to secret commissions :-

This business of corrupt bargains was a malignant canker; it was affecting bonesty in all, or in many, details of the relations of life, and was not confined to commercial relations. It was dishonest to fair trading; it was dishonest to the fair employer; it broke down that principle of morality which ought to be preserved among men who desired to cultivate and deserve honesty.

For some time past there have been whispers that some members of our profession are directly interested in certain nursing homes and are pecuniarily concerned in the prosperity of these institutions as commercial undertakings. This alliance is fraught with many evils, but there is one which is particularly grave-namely, the temptation and opportunity it affords to send patients into these homes unnecessarily for treatment, which may be more or less unnecessary also. But the confederacy manifests itself in another way. A few days ago the proprietress of a long-established home asked my advice and opinion respecting a proposal which had been made to her by a surgeon to the effect that she should pay him a commission on all the patients he should send to her. She asked whether it was usual and right for a medical man to ask or to receive such commissions. I replied that I hoped and believed it was not usual and that it was certainly not right. Is the " malignant canker" attacking our profession? If so, the sooner it is eradicated the better.

July 23 rd, 1896.

$$
\text { I am, Sirs, yours truly, }
$$

JOHN TWEEDY.

\section{"THE QUESTION OF MEDICAL DEFENCE." To the Editors of THE LANCET.}

SiRs,-It is a matter of regret that you should have still to speak in the plural number of Medical Defence Societies, the object of which is the same and which are respectively presided over by gentlemen of the highest scientific and personal character.

To me it seems also a matter of regret that as regards one of these there is a prospect of its being merged or lost in the great medical association which was founded for nearly all medical purposes but this one of medical defence. The number of members of these societies and the number of cases in which the action of the societies is invoked are proof of the necessity for specialising this work and having a society to do it. I cannot see the necessity for two societies, but as to the necessity for a special society I have no doubt. It is, of course, possible that as the mere section of a great association, a defence or protection committee may have the efficiency of our present societies, but I very much doubt it; and I very much doubt whether members of the Medical Defence Union-which is understood to contemplate parting with its identity after haring achieved a creditable reputation for usefulness-will think so. It may be said that this is a mere domestic matter of compatibility of temper between two societies, and to a certain extent this may be admitted. But neither the leaders of the British Medical Association nor of the Medical Defence Union would take it as a compliment to have it said that their malgamation or their separation was a matter of indifference to the profession to which they both have done such signal service. The functions of the British Medical Associ. ation are already legion, and further multiplication may only lead to inefficiency and disappointment. It is evident that among its own members there is grave doubt as to this new development and the form it should take. The words of Lord Melbourne will come to the minds of many "Can't you leave well alone?"-I am, Sirs, yours faithfully, July 27th.

M.D.

** Our correspondent, M.D., will observe that the same doubt has entered our minds. We have given expression to it in more than one article.-ED. L.

\section{To the Editors of THE LANCET.}

SiRs,--Your able leading article last week on this subject seems to me-I say it respectfully-to lack one thing, and that is a cordial recommendation to the profession to join one or other of the Defence Societies. Medical defence is a new want in the profession, or rather it is a want the seriousness of which we have only recently realised. It is not very imaginable that the mere supply of such societies could create a demand for them, from which it follows either that there is an increased tendency in the public to exact more from their medical attendants than is reasonable, or to be critical and ungenerous in their construction of professional service, or, worse still, that there is a growth of unprincipled or morbid classes that are ready to extort money from a medical man on any pretence whatever-classes to whom the very nature of medical practice gives special chances and opportunities.

It would be a mistake to suppose that the medical is the only profession that suffers such annoyances. They are experienced not infrequently by lawyers-not, indeed, in the gross and morbid forms in which medical men are often attacked, but in the form of charges of negligent and unskilful treatment of cases. I have not heard that the number of such cases is such as to have given rise to special defence societies in the legal profession, but they are not infrequent and are generally arranged witbout public appearance. This is the great service done to the medical profession by its defence and protection societies. They avert or arrest legal processes involving cost, worry, and publicity at such an extremely small expense that a medical man is unwise who willingly neglects to become a member. Of course, the first line of defence in every honest and fairly capable member of the profession is his carefulness to preserve bis own character and the reputation of his profession, and no society or number of societies will avail to protect men who do not so protect themselves.-I am, Sirs, yours faithfully, July 28th.

D. Vे.

\section{A ZEALOUS MEDICAL OFFICER OF HEALTH.}

To the Editors of THE LANCET.

Sins,- - The following case may be of interest as well as a help to others, especially to younger medical men beginning life. A few weeks ago a lad was brought to me suffering from a simple sore throat. I ordered him to bed and called after wards. A very doubtful and slight rash determined me in watching the patient and explicitly warning the mother that it might turn out to be scarlet fever. The parent being poor I called again gratuitously, each time explicitly warning bet of future possibilities. On calling in about two weeks from the date of the child being first ill I was told he was out, probably enjoying himself with other youths of the town. I asked if he were desquamating. "No, not the slightest signs." Still not satisfied, I examined the child that evening and next day and found him desquamating on the hands and body. I at once reported the case and advised removal. A few days afterwards I received a letter from the medical officer of health saying he "was informed " that I had told the parent four days after I first saw the boy that he was suffering from scarlet fever, and would I be so good as to give my explana. tion, as he was bound, \&c., to bring the matter before his committee. Many medical men would have replied to such a frivolous piece of hearsay in a very few lines, but instead I courteously informed this gentleman of the facts as I have given them-a result beneficial to the parish as well as to the boy. I certainly expected some apology, but 
neither apology nor thanks have I received. The case, at all events, is instructive and I would impress a few points on my brother practitioners. In all doubtful cases we should be most explicit in everything we say and never give a hasty opinion. We need not do so, as the law is fortunately clear on the question. The moment we pronounce the disease infectious we should notify at once and post the notification with our own hands. A short time ago I saw a boy with nothing but a white ratch about the size of a pea on his arula. I watched for scarlet fever and afterwards found my suspicions amply verified. Dealing at times with ignorant patients in these matters is always more or less of a worry, but we do not expect to be called upon for explanations obviously puerile and frequently irritating.

$$
\text { I am, Sirs, yours faithfully, }
$$

July 25th, 1896 EXPERIENTIA DOCET.

\section{SCOTLAND.}

(FROM OUR OWN CORRESPONDENTS )

\section{Edinburgh Royal Infirmary.}

The Pablic Health Committee of the Edinburgh Town Council have had before them a representation from Sir Henry Littlejohn, medical officer of health for the city, relating to the reconstruction of the Royal Infirmary laundry in Lauriston-place. This representation pointed out the many complaints the laundry had previously given rise to from residents in the neighbourhood, and maintained that in the interests of public health the laundry ought to be removed to the country. At the same meeting certain proprietors in the neighbourhood stated their views on the subject before the committee. The sub-committee, to whom Sir Henry Littlejohn's letter was remitted, met next day and expressed regret that the infirmary managers were to erec the laundry within the infirmary grounds. They regretted that it was not to be taken out of the city, where there would be more air and where the smell of the washing would not annoy dwellers in the neighbourhood.

\section{British Institute of Publio Nealth.}

The meetings of the Institute commenced in Glasgow on July 23rd with a formal reception of delegates by the Lord Prorost and magistrates in the Bute Hall of the University. After some remarks by the retiring President the Lord Provost, Sir James Bell, Bart., was installed as President and delivered an address to the delegates, taking as his subject the Sanitary Progress of Glasgow during the past Fifty Years. The statistics submitted showed that, as compared with the citizen of fifty years ago, a person of his years of age has now an expectation of six years longer life. Another feature of the opening day's proceedings was a highly successful and entertaining address by Professor William Ramsay on the Smoke Nuisance, which he contended would be altogether removed if the practice of using coal were discontinued in favour of gas and coke. Some practical suggestions were submitted by which this end could be attained. Amongst the papers submitted to the various sections may be mentioned Dr. J. B. Russell's address on Dust as a Means of Infection; Ptomaine Poisoning, by Sir Charles A. Cameron ; "Return" Cases of Scarlet-fever, by Dr. A. K. Chalmers; and the Construction of Hospitals for the Treatment of Infectious Diseases, by Dr. Alexander Johnston. In the last-mentioned paper it was stated that the mortality from scarlet fever in Glasgow had fallen from 17 per cent. in 1874 to 4.9 in 1894. The Congress was entertained by the Corporation, the University, and the Faculty of Physicians and Surgeons. Saturday, which was devoted to excursions, was a most unfortunate day, the Feather being of the worst description.

\section{Medical Appointments.}

Ur. J.K. Kelly has been appointed surgeon in charge of the wards for diseases of women in the Glasgow Royal Infirmary, rice Dr. Stirton, resigned. $\mathrm{He}$ has consequently resigned his position as surgeon to the Samaritan Hospital. Th:e po:ition of clinical assistant at the Samaritan Hospital is also vacant and it has been decided that women candidates only shall be eligible. The post of vaccinator at the Royal Intizmary is racant by the death of Dr. Hugh Thomson.

\section{Glasgow University.}

At the summer graduation on July 21st the degree of H.D. was conferred upon fourteen gentlemen, four of these,
Mr. F. Dittmar, M.A., M.B., Mr. A. A. Gray, M.B., Mr. A. T. Nisbet, M.B., and Mr. Jas. Todd, M.B., being awarded "commendation" for their theses. Sixty-six candidates received the degrees of M.B. and C.M. Of these, two gained "Honours"-viz., Mr. Joseph Knight and Miss Madge Spiers Maclean; whilst Mr. S. Anderson, B.Sc., Mr. Hugh Calderwood, B.Sc., Mr. J. S. McKendrick, and Mr. J. A. Hope were "commended." The list included altogether five successful women candidates. The Brunton Memorial Prize, awarded to the most distinguished medical graduate of the year, has been gained by Mr. J. Knight, M.B. The Dill Prize, for the best thesis presented for the degree of M.D. in the years 1893-96, has been gained by Mr. W. R. Jack, B.Sc., M.D. In the medical classes the following distinctions have been gained : Forensic Medicine, medal, Miss Daisy Clark; Practical Pharmacy, medal, Mr. Alex. Wilson; Diseases of Women, medal, Mr. J. S. McKendrick; Clinical Medicine (Dr. Gairdner), medal, Mr. J. D. Cochrane, Mr. Hugh Calderwood proxime accessit; Clinical Medicine (Dr. McCall Anderson), Mr. Andrew C. Wilson, B.Sc.; Practical Physiology, medal, Mr. Alex. Wilson; Embryology, prizemen, Mr. Robert Fullarton, M.A., and $\mathrm{Mr}$. Fredk. E. Stokes ; Practical Zoology, medal, Mr. David Kyle; Botany, medallists, Mr. Jas. D. Lickley and Mr. J. D. Richmond; Practical Chemistry, medal, Mr. Alex. Birch; Practical Pathology, medal, Mr. Wm. Webster; Insanity, Mackintosh Bursar, Mr. Thos. Hunter, M.A.; Diseases of the Ear, prizes, Mr. Norman McNair, B.Sc., and Mr. D. L. Cairns.

\section{Aberdeen Royal Infirmary.}

THE rule requiring in-door patients to produce recommendatory "lines" before admission has been abrogated.

\section{Aberdeen Hospital Saturday Fund.}

The receipts have been found to be $£ 113312 s .5 d$. and the expenditure $£ 1567 \mathrm{~s} .9 \mathrm{~d}$. The sum of $£ 950$ is recommended to be allocated as follows:-Aberdeen Royal Infirmary, $£ 550$; Aberdeen Royal Hospital for Sick Children, £100; Aberdeen General Dispensary, $£ 100$; Convalescent Hospital, Pitfodels, Aberdeen, $£ 50$; Aberdeen District Nursing Association, $£ 50$; Aberdeen Ophthalmic Institution, $£ 50$; Hospital for Incurables, Morningfield, Aberdeen, £50 ; leaving a balance of $£ 274 s$. $8 d$. to be carried forward.

\section{Marischal College Extension.}

The University buildings extension sites and plans committee have instructed Mr. A. Marshall Mackenzie, A.R.S.A., the architect, to procure tenders for the construction of a south wing for a distance of eighty feet at a cost of about $£ 11,000$. Accommodation will be provided for the Natural Philosophy department, the intention being on the completion of the new buildings to transfer the teaching of physics from King's College, Old Aberdeen, to Marischal College. The wing will at present end beside Greyfriars Church, and the erection of a terminal tower will afterwards have to be arranged. Nothing definite has yet been arranged as to additional accommodation for the Natural History Department.

\section{Death of Dr. T. G. Weir.}

I regret to announce the death of Dr. Thomas Graham Weir. He was one of the oldest practitioners in Edinburgh and son of an officer who had served under Nelson at the battle of the Nile. He was educated at the High School of Edinburgh and at a school in England, after which he entered upon the study of medicine. In 1837 he took the degree of M.D. Edin. and in 1847 was elected a Fellow of the Royal College of Physicians of Edinburgh. After graduating at the Edinburgh University he spent some time in study at various Continental medical schools. Dr. Graham Weir was one of the original founders of the Sick Children's Hospital in Edinburgh in 1859, and in the course of a long professional career filled many important offices in connexion with the medical institutions of Edinburgh. He was consulting physician to the Royal Hospital for Sick Children, consulting physician accoucheur to the New Town Dispensary, and honorary physician to the Royal Infirmary at the time of his death. Dr. Graham Weir, who died on the 20th inst., was eighty-five years of age, and in him Edinburgh has lost one of its most respected practitioners. Before his death he had to a great extent withdrawn from private practice, but those of his older patients whom he still continued to see will lose in him more than a medical attendant-one whom they speedily learned to look on as an affectionate friend.

July 27th. 